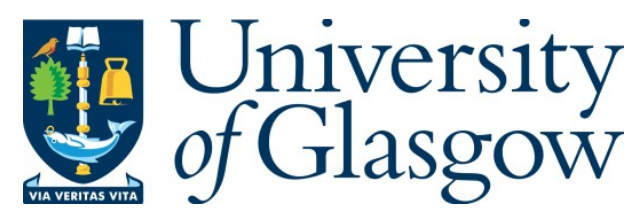

Armstrong, S., and Lam, A. (2016) Policy as a Crime Scene. In: Armstrong, S.,

Blaustein, J. and Henry, A. (eds.) Reflexivity and Criminal Justice: Intersections of Policy, Practice and Research. Palgrave Macmillan: Basingstoke, pp. 101-122. ISBN 9781137546425.

There may be differences between this version and the published version. You are advised to consult the publisher's version if you wish to cite from it.

http://eprints.gla.ac.uk/134487/

Deposited on: 23 January 2017

Enlighten - Research publications by members of the University of Glasgow http://eprints.gla.ac.uk 


\section{Chapter 5 Policy as a crime scene}

Sarah Armstrong (University of Glasgow, UK) and Anita Lam (York University, Canada)

Abstract: This paper explores how policy constructs the objects it seeks to regulate, taking as its case the setting of penal policy in contemporary Scotland. It employs two distinctive theoretical frames to develop the analysis: Science and Technology Studies (STS) and 'scene theory' a body of work in cultural studies. These offer distinctive lenses that bring into focus how the technologies of policy - statistical reports, independent Commissions, research advice - help produce populations that require intervention. The penal policy setting in question, we argue, can be understood in the same way as a crime scene, where investigators must re-construct forensically a narrative that will be legally validated. In line with the theme of this book, it offers a reflexive account of how researchers themselves are drawn into and participate as key witnesses in the scene, testifying to 'facts' about a crime that may have never taken place. The article aims to make the case for the potential of STS and scene theory in producing insights about our understanding of policy, particularly criminal justice policy. In doing this, it also offers a critique of the formation of the criminological discipline in a way that has side-lined policy as an 'administrative' rather than critical intellectual issue.

Key words: penal policy, STS, scene theory, statistics, short prison sentences

Mark worked in a McDonald's once but has no job now. He is not very close to his family and has no specific plans for his future. He is only 19, though, and who knows how he might develop. Katrina is 29, a decade older than Mark. She has two children; her four year old has major sight and hearing impairments as well as a lung problem, and she has spent more time in hospitals than she cares to recall. Her parents are getting older, and one of them recently had a stroke, which is a source of deep stress for her. She is very close to her family and anxious to be with them.

Mark and Katrina have as much in common as two people who might find themselves in a supermarket at the same time. Perhaps there are predictable similarities: maybe they live in the same neighbourhood as the shop. Perhaps there are random ones like sharing a birthday. But while Mark and Katrina might otherwise pass each other on the street without stopping, they have been brought together and constituted as part of a single population. ${ }^{1}$ They are both prisoners serving sentences of six months or less. While people in prison by definition have shared interests and needs and in that sense might be considered to form a group, whether or not they know each other or would choose each other's company, it is not only the fact of their confinement that draws them together. An ongoing policy drive in Scotland (as in many other places) aims to reduce the use of short prison sentences, and is targeting in particular those serving six months or less (Scottish Government 2015; Scottish Prisons Commission 2008). By drawing a circle around people serving a particular sentence, a policy process has also constituted them as an empirical phenomenon, that is, as a distinct entity that has particular origins, traits 
and needs. This chapter is about how policy does not simply target particular actors and social situations but participates in making them as well. By exploring this process in action through a case study of penal policy, it hopes to demonstrate the need to study policy in criminology as part of a core research programme, where policy is as much a frontline field of inquiry as street corners and jail cells. And just as the state of research on these latter sites of action has advanced significantly, so too, could studies of policy be nurtured, by developing a greater capacity for critical and reflexive engagement, and deploying a wider and more inspired range of methods than is currently the case.

We develop this project, and model one approach to reflexivity, by conceiving of policy as a crime scene. One reason we adopt 'scene thinking' is because scenes, unlike sites, are not specific places, but instead comprise a set of spaces, affects, materials and discourses that together form a distinctive arena of action and culture (Straw 2001). This troubles conventional understandings of policy as a discrete and durable entity made in one place and delivered to another in the attempt to change behaviour (Gordon et al. 1977), reflecting instead the ways that policy can be observed constantly on the move, forming and re-forming, contributing to, constituting and being constituted by the spaces and discourses it travels through (Clarke et al. 2015). The crime scene metaphor also is useful because it situates policy at the centre of investigation; policy scenes ought to be as thoroughly investigated and scrutinized as crime scenes themselves. Like detectives tasked with inspecting, probing and exploring the construction of crime scenes, we turn the same kind of penetrating gaze onto policy itself. Yoked to an exercise in reflexive and critical questioning, we additionally ask what role criminology plays in producing and reacting to policy, particularly policy's constructions of crime.

Like other kinds of 'scientific facts' (Latour and Woolgar 1986), 'crime' is itself produced by the very processes that claim to discover and study it. 'Crime' then is at least partially produced by academic criminology, and academic criminologists have positioned themselves as legitimate producers of expert knowledge on crime, criminality and criminal justice. Yet academic criminology has had little occasion to be reflexive - that is, occasion to study and analyse the conditions of its own production of knowledge in order to overcome, change or critique them (Bourdieu 2004). Indeed, criminologists rarely examine the conditions that underlie the production of academic criminological knowledge. Perhaps this is related to some criminologists' reticence to answering questions about the discipline itself, as such questions are not seen as intellectually stimulating, or worthy of criminologists' time and commitment (Bosworth and 
Hoyle 2011: 8-9). The pursuit of such reflexive questions about the criminological field, however, is of pressing importance when it comes to explaining why criminologists have often disregarded policy settings out of hand as uninteresting and empirically irrelevant cultural sites for inquiry, despite the fact that these settings produce knowledge, facts and subjects about the 'crime problem' that have a profound impact on the production of academic criminology. The knowledge products of policy processes become data for empirical investigations; they become the categories through which academic criminologists think; they serve as fuel for critical interrogation and inquiry; they produce the phenomena and actors that provide the criminological field's raison d'être.

The paper is organised as follows. First, we identify and discuss a double absence of policy in criminology. This refers to the relative lack of criminological research which directly engages policy on one level, and on the other, where research does address policy, it is treated as a given, a black box into which evidence is fed (or not) and from which good ideas and practices emerge (or not). We then introduce our approach to policy as a crime scene, drawing from some of the literature on 'scene thinking'. This assists in the broadening out of conventional definitions of policy. We believe the scene frame assists centring policy without taking away from its complexity as product, generator and setting of social and cultural processes. Finally, we bring this frame to bear on a case study of penal policy, specifically policy and reform on short prison sentences. Here we return to Mark and Katrina: in their re-cast role as subjects of penal policy, they become data doubles (Haggerty and Ericson 2000) and come to have a double presence, as real people confined in physical prisons and as part of an imaginary of a punishment problem that policy exists to solve.

\section{Policy's double absence}

Policy is missing in two ways in criminology. First, and with important qualifications, it is missing as a central topic of study. One qualification to this is the incorporation of criminal justice itself as an area of research alongside research on crime, which has led to a focus on the rules and politics through which justice actors and institutions govern and control others, and therefore on the policies which enable or constrain them. For example, drug policy, sentencing policy, victims policy are now as much a part of the criminological research agenda as the underlying phenomena creating the needs for policy. Another qualification is the intensification of pressure, as in the UK's 'research impact' agenda, for researchers to demonstrate the importance of their work in terms of how directly it influences policy and practice. While such developments mean 
that policy is never far from view in criminological research, it is rarely the subject of research itself. It is something that research might inform, but not part of the empirical world under study.

A second way in which policy is missing in criminology, ironically, is in research on policy itself. Where policy is the topic of study, the focus tends to be on content and outcomes rather than processes, and the analysis tends to adopt a rationalist and instrumentalist perspective (as criminologists have observed, e.g. Newburn 2003). That is, research addresses how well policy achieves (or does not achieve) its aims, what its unintended consequences have been, who its winners and losers are. But within this approach to policy, there remains, to quote Harding in this volume, a 'hollow space'. What is policy? Who are its actors, and what are its lives and loves (Riles 2005)? How does it do its work, and what does this work consist of? What are its inner workings and politics, its particular resources and constructions of the world? These are the sorts of questions that criminologists apply to phenomena from drug dealers to courts and prisons but rarely to the processes through which drugs are criminalised and courts and prisons organised. Policy is 'black boxed', treated as a given like an independent variable, and 'no longer open for debate' (Riles 2005: 999, n84; Latour 1987).

One senses that the double absence of policy in criminological research arises not from its lack of relevance or potential to contribute to central questions for the discipline but due to other causes. We posit one of these as the troubled relationship the field has long had with the state, arising from the assumption that the relationship between state and academia is a parasitic, oneway relationship. In a sharply worded argument, Hope and Walters (2008: 23) called upon academic criminologists to boycott government research because the government 'manipulates or cherry-picks criminological knowledge and produces distorted pictures of the "crime problem"' for political gain. Academic legitimacy, they argue, must not be granted to such a corrupt process. To dissociate academic knowledges from its potential corruption and contamination by the state, criminologists have tended to conceive of academic and policy sites of criminological production as distinct, bounded realms that ought to remain separate from each other. This conceptual separation between academic criminology and policy is tied to the field's overall attempt at establishing itself as a properly scientific discipline, distinct from the institutions and impulses of governance which initially sustained it. We can see academic criminology's resistance to policy settings in reflections on the field's increasing fragmentation (Bosworth and Hoyle 2011; Ericson and Carriere 1994) and pluralism (Loader and Sparks 2011), 
which build on accounts of the development of the discipline along the lines of two particular knowledge projects (Garland 2002): a governmental project where research is used to more efficiently administer justice through more effective policies directed at the management and control of certain populations; and an etiological project where inquiry is aimed at explaining the root causes of crime. While these two projects can converge, they have often been placed in competition with one another in a zero-sum game of knowledge production and legitimation. Although we can trace the governmental and policy project back to the origins of the discipline (Garland 2002), it - now often re-articulated as 'administrative criminology' - has been currently constructed as a 'pejorative label' (Clarke and Felson 2011: 25). Few, if any, academic criminologists would locate their work under this category precisely because it comes with an implicit stamp of disapproval from colleagues (Cullen 2011; Hough 2014). Even though administrative criminology is a fuzzily and nebulously defined site with boundaries that have increasingly blurred with those of mainstream criminology (O’Malley 1996) and critical criminology (Pavlich 2000; Rock 1994), it currently provides both academic and critical criminologies with a chief 'sparring partner' (Young 1986: 7) and binary opposite. As an imagined site of knowledge production, administrative criminology appears as a monolithic strawman, supporting the boundary work (Gieryn 1983) and occasional evangelizing (Carlen 2011) of otherwise fragmented academic criminologies. That is, the boundaries of academic criminology, in both its mainstream and critical modes, have been erected to legitimate (and represent their own activity as) knowledge produced independent of politics and the market, in an attempt at sealing off such knowledge production from policy processes.

\section{Where is policy? Scene thinking}

If policy is not 'black boxed' nor accepted unquestioningly as a durable thing: what is it, how might one engage it, and just as pertinent, where is it? The question of 'where' emerges once we stop treating the meaning and actors of policy as self-evident. If we cannot assume it is an object with sealed boundaries, the where becomes a central aspect of interrogation. Critical policy scholars attempt to do this by moving beyond 'a conception of policy as [a thing that moves] horizontally, across sites, and vertically from policymaking centres to "implementation" on the front line [towards envisioning] "the life of social policy - a process rather than a thing - as complex and convoluted, tracing and leaving traces of meaning and power as it travels across sites and through persons"” (Clarke et al. 2015: 9-10, quoting Kingfisher 2013). Far from being fixed, policy settings refuse to fit into the neat boundaries of a circumscribed arena of action, where there are clear delineations of a beginning and end. Even policy's products escape 
attempts to bind them to specific places and institutions, as policies and policy knowledges can travel from local sites of production within the closed corridors of bureaucracy to international, public arenas for discussion and back again. To capture the messiness and amorphous nature of policy settings and their products, we speak of and target policy not as a discrete site, but rather as a scene. In so doing, we explicitly treat policy like any other object of cultural analysis, as the concept of 'scene' has been primarily used to analyse cultural phenomena ranging from popular music scenes (e.g. Bennett and Peterson 2004; Shank 1994), youth subcultures (e.g. Bennett 1999; Glass 2012), and urban life (e.g. Boutros and Straw 2010; Irwin 1977). Policy, often assumed to encompass the technical activities of bureaucrats, then is placed on the same analytic footing as hip, effervescent, and exciting cultural scenes, and consequently presumed to be as interesting and disruptive a phenomenon. We recognise the need to do something to entice the criminologist into studying what feels distant in space and meaning from the visceral excitement of the street and its gangs. Moreover, like Riles, we hope to 'bring the technical into view not as an effect or a byproduct, a tool of more important agents and forces, but as the protagonist of its own account' (Riles 2005: 985).

Our turn toward scene thinking aligns with the ways in which 'policy worlds' have been conceived in anthropology and interpretative political science. Specifically, the term 'policy worlds' implies that policies ought not to be considered essentialised or bounded entities, but rather as migrating windows onto political processes, in which multiple actors, agents, ideas and technologies interact at different sites, in order to create or consolidate new rationalities of governance and regimes of knowledge and power (Shore, Wright and Peros 2011: 2). Such a processual perspective opposes the conventional practitioner perspective, which casts policy in terms of an 'authoritative instrumentalism.' That is, practitioners tend to assume that policies are objective entities that exist 'out there' as the product of decisions made by some visible, rational authority to solve a particular problem. Like the notion of 'policy worlds,' we introduce the idea of 'policy scenes' to counteract presumptions that policy processes are best described as linear, hierarchical and logical. Like policy worlds, policy scenes are similarly anti-essentialising, flexible entities with elastic and fluid boundaries.

As Will Straw (2001) has argued, 'scene' is a slippery concept in cultural analysis because it has been called upon to perform multiple tasks, describing unities of highly variable scale and scope that range from local clusters of activity to practices scattered across the globe. Some of these unities are bound to specific local places, while others are loosely grouped together only through 
a hazy coherence between sets of practices, affinities and tastes. For example, when cultural studies scholars have examined music scenes, the term 'scene' has been applied to designate the following phenomena: 1) the recurring congregation of people at a time and place (e.g. a specific bar or café), or in Bruno Latour's $(2005,1987)$ terms, a point of assembly, such as a laboratory or centre of calculation, for multiple and diverse actors to do transformative work; 2) the movement of people and products along streets or strips between different spaces of congregation, or in more Foucauldian terms, the migration of techniques into new contexts and settings; and 3) all the other spatially dispersed places and activities, such as social media promotion or journalistic coverage of a music scene, that surround and support a particular cultural affinity or preference. In short, scenes can simultaneously characterise collectivities, spaces of assembly, workspaces of transformation, spaces of travel and circulation, and ethical and mediated worlds (Straw 2015). Moreover, 'scenes' might not name a thing or a phenomenon at all. Instead, Woo, Rennie and Poyntz (2015: 292) insist that 'scene' is an orientation to things, or a way of seeing the world. Specifically, scene thinking represents a decision to treat a set of individuals, institutions and practices as if they constitute a scene. Arguably, this is what members themselves do, sweeping discrete people, places, events and artefacts up into what comes to be called a scene. Focusing on the scene switches figure and ground, bringing takenfor-granted conditions of possibility to the fore. In the hands of different analysts, these might include spaces, organizations and infrastructures; affects, emotions and structures of feeling; or routes, networks and practices that make a particular scene part of the texture of a place. But to identify any or all of these as constitutive features of a scene sensitizes us to the ways they provide the setting for action.

Following Woo, Rennie and Poyntz, we think through policy scenes as slippery settings for action that sweep together a range of spaces, actors and materials, all the while producing 'crime' and its actors through a particular set of practices and affinities across different institutional sites. Policy scenes have a messy indeterminacy, but give coherence to something that might otherwise have an amorphous and relatively unbounded shape. The concept of 'thinking through' is also instructive particularly when it comes to analysing the production of policy because it urges us to reject the impulse to turn an analysis of policy into an examination of policy makers, a studying up exercise limited to the places where elites work. When policy itself is centred as the thing to be explained, it requires 'studying through' - that is, following a 'process of political transformation through space and time' (Wright and Rheinhold 2011: 101). From the outset, 
then, while policy makers are part of the policy community so, too, are the people whose lives will be regulated through policy change.

\section{Policy as crime scene: The case of penal reform}

Katrina and Mark were two of 22 people interviewed while serving a short prison sentence in Scotland in 2010. ${ }^{2}$ At the time they were in prison, the Scottish Government was pursuing major changes in sentencing policy as part of a larger drive to address chronically high and rising imprisonment rates in this part of the $\mathrm{UK}^{3}$ A recently elected nationalist Government had placed a high priority on criminal justice reform, partly as the arena in which it would sharply delineate its differences from prior UK and Scottish governments. In contrast to the direction of prison policy in England and Wales, Scotland adopted an explicitly reductionist and sceptical attitude towards prison, framing high prison populations not as evidence of effective crime control but as a symptom of civic failure. One of the Government's first acts in the area of justice policy was to pull out of advanced contract discussions to build new prisons, and reverse the pro-privatisation stance of the previous administration (Mulholland 2007). The new Government positioned Scotland as part of a network of small, welfarist northern European nations: 'The Government refuses to believe that the Scottish people are inherently bad or that there is any genetic reason why we should be locking up twice as many offenders as Ireland or Norway' (MacAskill 2007). An independent Scottish Prisons Commission, composed of justice officials and civic leaders, was charged with gathering evidence and views to '[c]onsider how imprisonment is currently used in Scotland and how that use fits with the Government's wider strategic objectives. ${ }^{4}$

An expansive and diffuse list of 'drivers' of prison growth emerged over the Commission's seven months of deliberations. These included rising rates of recalling people on parole to prison and disproportionate growth in the number of women in prison (SPC 2008). However, even before any evidence had been gathered, short prison sentences were identified as a key issue of concern, raised in the Cabinet Secretary of Justice's speech launching the Commission: 'The Scottish Prison Service's ability to work with serious offenders ... is being compromised by having to deal with the churn created by a large number of short sentences' (MacAskill 2007). This context sets part of the scene in which penal policy coagulated a series of long running debates and perspectives about the 'prison problem' in Scotland. Thus, it offers a discrete opportunity to engage with policy as a scene and to explore its cultural dynamics and reverberations. 
A brief word on method: Sarah was engaged in this policy scene as both a researcher of it, and a researcher in it (see also, Blaustein 2015). She along with another academic acted as an informal adviser to the Prisons Commission, supporting their gathering and analysis of evidence during 2008. Following on from this, an ESRC research grant funded her for two years to conduct an 'ethnography of penal policy' in which the aftermath of the Commission's work was followed through numerous sites from civil servant offices to conferences to prison wings. The methodological orientation drew on work by anthropologists of policy (Shore and Wright 1997; Strathern 2000) and increasingly STS research, particularly on governance (Riles 2005, 2006; Davis et al. 2012; Engle Merry et al. 2015; Star 1999). At the same time, she remained a researcher in a criminological centre conducting Government-contracted and independent work on the criminal justice system of Scotland and employing conventional methods of qualitative and quantitative research. This gives a sense of the points of access to the scene, but also demonstrates the fluidity of roles of a single researcher, and the entanglement of roles generally in criminal justice research. At different points, the researcher may act as administrative criminologist, critical criminologist, autoethnographer or activist. This opens up, though not within the space constraints of this chapter, the need to question and explore the sharp division often claimed to mark the boundary between academic and critical criminology (as modes of independent knowledge production) on one side, and administrative criminology (knowledge production often characterised as reactive and compliant) on the other.

In all the sites that made up this particular policy scene, the prisoner, unsurprisingly, was the focus of attention. However, and also unsurprisingly, no prisoners or prisoner groups were invited to formally participate in the Commission process, or in the legislative process that eventually produced the policy instruments to implement reform (see also, Blaustein, this volume). This raised a question for us about how prisoners, or any target population, can achieve presence in the policy processes that concern them. Put another way, how are actors located in different parts of a policy scene brought into conversation or made visible to each other? This is not just an issue about the spatial distance between a prison where prisoners live, and a Government office where civil servants draft bills. There are also social, material and cultural distances to overcome. People confined in prison and the managers and policymakers who govern the conditions of their confinement use different vocabularies, have different understandings of punishment, and different reasons for their involvement in penal policy. They also have varying levels of access to technologies of communication and means of representation. 
We want to isolate two modes of representation, or techniques of presence, that operated in this policy scene, both related to the issue of short prison sentences. The first is statistical information as a way of documenting the reality of prison, and the second is a research project on 'user views of short sentences' that made Mark, Katrina and a number of others visible in this policy scene. As noted, short sentences were identified at the outset as a problem and therefore became a focus for developing recommendations. Although short prison sentences have been viewed as undesirable since the $19^{\text {th }}$ century (Faraldo Cabana 2015), what kinds of problems do short prison sentences cause? The conventional critique is that a short spell in prison offers insufficient opportunity either to inflict enough pain to deter, or enough time to trigger longterm rehabilitation: 'It could hardly be clearer that short-term imprisonment fails to end criminal careers' (SPC 2008: 39). The Prisons Commission further commented that the prevalence of short prison sentences constituted a 'problematic and largely unnecessary use of prison' (Id.: 13). The quantitative reality of a prison problem rooted in short sentences was focused on one key statistic: the percentage of prison sentences handed down by courts that were for six months or less. At the time of the Commission's role in prison policy, this figure was 83\% (SPC 2008: 13). That is, fewer than two in ten prison sentences pronounced in Scotland were for longer than than six months, a statistic which was felt to establish a powerful and self-evident case of the overuse of short sentences. This rested on two premises: first, that the uncontested proper use of prison is as a place of confinement exclusively for those who commit such serious and violent crimes that they must be kept away from society for a substantial period; and second, a spell of imprisonment for less than a minimal period (typically one year ${ }^{5}$ ) is pointless, offering no likelihood either of punishment or rehabilitation.

The $83 \%$ figure was taken from court statistics, positioning the cause of short sentences as sentencers themselves. This is evident in the Policy Memorandum to legislation following from the Commission's work, which stated that the objective of the law would be to 'ensure appropriate use is made by courts of short term custodial sentences' (Scottish Parliament 2009: 12). At this point in the policy scene's narration of the short prison sentence, a crucial shift in representation occurred. To substantiate the effectiveness of the alternative to short prison sentences, expanded use of community-based sanctions, policy makers needed to know about the short-sentenced population. Who were the people on short sentences? What were their needs, and what kind of penal interventions would they respond to? Thus, a problematic system practice was turned into a problematic empirical population - the six-months-or-less prisoner. 
Although a shared length of sentence is a thin basis for group identity, it nevertheless usefully coordinated the organization of a variety of information and perspectives circulating in the policy scene. For example, the wrongness of putting people in prison for short periods was established by aggregating information about prisoners' backgrounds, such as the prevalence of drug and alcohol problems as well as difficult personal histories (Figure 5.1). Such information aimed at concatenating a group that was 'troubled and troubling rather than dangerous' (SPC 2008: 2).

Figure 5.1 Graphic excerpted from Scotland's Choice: The Report of the Scottish Prisons Commission

\section{FIGURE 4: PRISONERS' BACKGROUNDS²2}

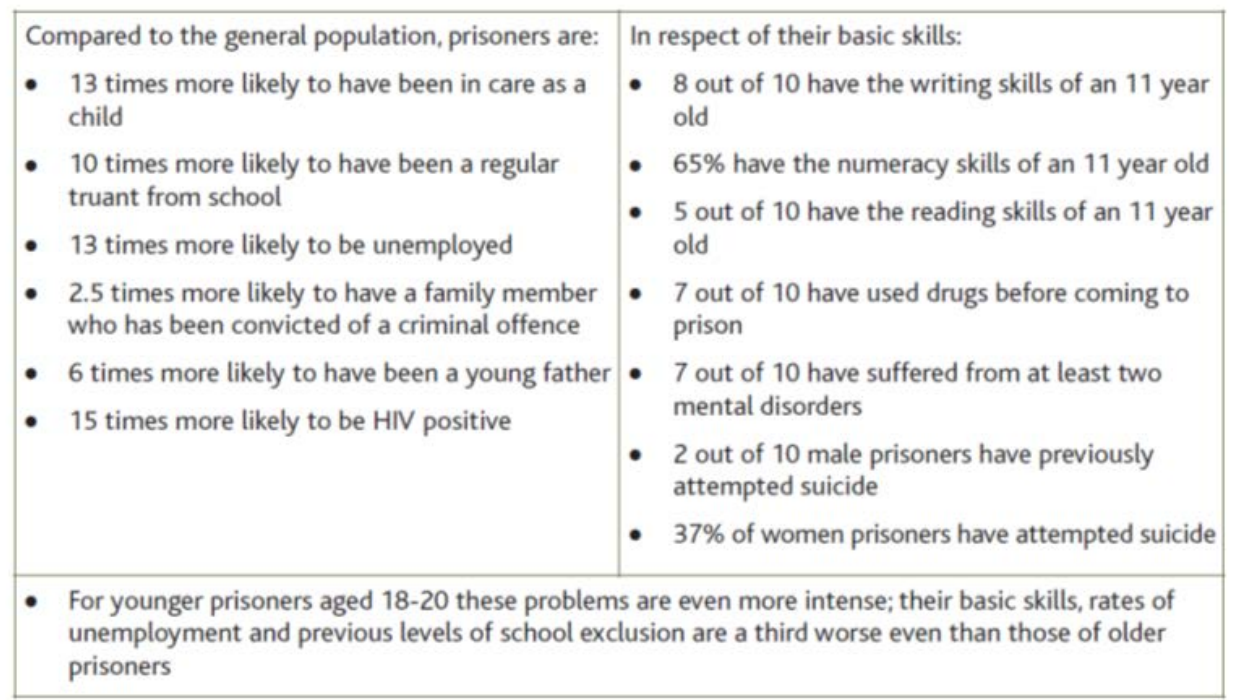

Source: Scottish Prisons Commission, Scotland's Choice, 2008: 16.

Although the graphic includes statistics about prisoners regardless of sentence length, this data was deployed in arguments for reducing or eliminating the use of imprisonment only for those serving the shortest sentences. Hence, through statistical documentation, six-months-or-less prisoners were fleshed out by their histories of deprivation and trauma (which provided evidence of both a cause of their imprisonment and its unfairness) and were foregrounded and connected to each other, allowing the substance abuse issues, marginalization and victimization of other kinds of prisoners, or of people not in prison, to fade into the background. Short prison sentences were linked to and gradually conflated with 'the least well off communities in Scotland' (SPC 2008: 16). In this way six-months-or-less prisoners were constructed as a distinct group based on shared characteristics, needs, and geographic locations.. The more those in the policy scene dwelled on the characteristics and needs of this population, the more real its existence, and therefore presence, seemed to be. 
The presence and participation of prisoners in this policy process through the abstract forms of reports and statistics materialises them as particular kinds of analytical objects. As a policy object, the prisoner is created not only by a particular mode of presence, but also by a set of absences absences in terms of other ways of participating, of 'realities that are necessarily absent, that cannot be brought to presence' (Law and Singleton 2005: 12). Abstract representations of prisoners then are one iteration of a pattern of presences and absences. The processing and segregation of prisoners through their statistical invocations allowed for the specification of what increasingly came to be thought of as a natural object: the six-months-or-less prisoner. By contrast to other abstract formations of prisoners or prisons, the eligibility of this prisoner within policy deliberations was justified by the degree to which it seemed able to explain penal expansion. Bringing this group into presence, however, simultaneously rendered absent and implicitly constructed other kinds of presence/absence binaries. For example, lifers were denied presence as a 'driver' of penal expansion despite constituting a growing part of the prison population as well (from 11\% of the prison population in 2002 to 13\% in 2012, Scottish Government 2012). The lifers' absence implied their lack of eligibility to be a part of penal reform, serving to construct and legitimate prison as a place for long-term institutionalization. At the same time, people in prison were categorically constructed as serious/not serious or dangerous/not dangerous according to their length of time in it, translating a problem of (squeezed penal) space into a problem of (sentenced) time.

Already we are hoping to suggest that what might be dismissed as the sterility of statistics and the exclusion of 'real' bodies in policy, as compared to, say, traditional prison ethnography, is more complicated and carries its own consequences for constituting the physical reality of imprisonment. The presence of abstract and quantified prisoners in this site of the policy scene was no less real for not involving actual bodies. This abstract prisoner, in other words, was not a mute stand-in for a prisoner living somewhere else, but its 'data double' (Haggerty and Ericson 2000: 613, quoting Poster 1990). Data doubles involve 'the multiplication of the individual, the constitution of an additional self' that 'ostensibly refer[s] back to particular individuals, [but] transcends a purely representational idiom' (Haggerty and Ericson 2000: 613-4). The data double transforms 'the body into pure information, such that it can be rendered more mobile and comparable' (Haggerty and Ericson 2000: 613). In this case, individuals about whom little is known became a coherent group who would be expected to have similar needs and behavioural responses that could be addressed through the same policy instruments. Hence the data double creates a more manageable population for policy than the physical prisoners spread across the 
country. The six-months-or-less prisoner fixed in the cells of a spreadsheet could be tracked and followed from year to year and therefore used as a marker of the reform's success or failure in a way it would have been physically impossible to follow the real prisoners who turnover in their dozens on a daily basis.

Direct involvement and observation of a moment in a policy scene, as in this case study, allows one to detail the 'discursive and material practices through which people create the regularized patterns which both enable and constrain them' (Shore and Wright 2011: 7). In 2009-10, Sarah and another colleague (Armstrong and Weaver 2010) sought to gather the views of the people who would be affected by changes to short sentences. This research was set within a wider turn towards including user voices in policy processes, a shift encouraged by Scottish Government officials. Enter Mark, Katrina and 20 other people in prison and a further 13 serving community sentences (Weaver and Armstrong 2011). Despite being asked questions focused on their experiences and views of sentences, prison and the criminal justice system, many of these research informants spontaneously opened up about their lives, particularly relating to issues of family, hope and hopelessness, jobs and substance abuse issues. So talk about self and talk about system were intermingled in interview transcripts, and our attempt to include voices on the experiences of punishment were dominated by biographical accounts of the punished. Perhaps this is not surprising in that the biographical - particularly the life history - is a genre that our informants were required to practice endlessly through their involvement in criminal justice activities (by social workers, lawyers, courts and risk assessors).

Interviewer: what would you say the impact of your prison sentence has been?

Respondent: Chhhhhhuh, don't know it's just, it gets me fucked with the missus. [Are there any positives of prison?] I've got two weans one with the missus and another, one up here, mah step wean but I brought her up. Just a [??], just pure nuts going on out there now. So I'd rather be in here because [of] all the social workers (unpublished interview transcript excerpt).

Interviewer: have you been on remand before?

Respondent: [Pause] uh yeah, em I've got a wee bit of a problematic relationship with my parents? Em and I come from a really, really strict background and me and 
mah dad have had some conflict before. And um he's got me charged with breach of the peace; it's just 'cause and it's just his way of annoyin' me. When more often than not he should be the person done for breach of the peace (unpublished interview transcript excerpt).

It can be seen here that not only were problems of prison articulated from the top, in elite policy settings, as problems of prisoners, but prisoners themselves were articulating prison in terms of their personal lives and backgrounds. By supplying to the policy scene such personal stories, our research tended to confirm and give life to six-months-or-less prisoners as an empirical phenomenon. 'User voices' in research are always mediated; in this case they were mediated through the way we designed, carried out and disseminated our research. The 35 people who participated in the research were 35 specimens establishing the natural existence of a population, a species to be discovered rather than made. At the end of the user views of punishment project, we prepared two long research reports which attempted to convey some of the qualifications, reflections and complications of the work, findings that resisted explanation in terms of people with drug problems, family support desires and habitual offending (http://www.sccjr.ac.uk/projects/user-views-of-punishment/). However, in order for our work to be visible within our own institutional contexts - the university and the publish-or-perish imperative manifest in the UK through the Research Excellence Framework- we had to disseminate it in the recognised and validated form of the peer-reviewed journal article, a format which squeezes space for raising complications, hesitations and doubt (Armstrong and Weaver 2013).

In the translation from research report to peer-reviewed journal article, therefore, ambiguities, nuances and contradictions were lost, even though these would have challenged attempts to understand this set of research participants as a coherent social or even policy group. Some people we spoke to did not share the background commonly ascribed to those in prison, of being poor or uneducated. Some did not fit the policy construction that short sentences are a proxy for less serious offending patterns (a guard said in passing while a prisoner was about to be interviewed, alone in a room, 'You ok with sex offenders? He's got long-term previous...', field notes). While family contact has become a mantra in rehabilitation discourse, family for these research participants was as often the cause of problems including offending, as the alleviation of it; sometimes it was both (Armstrong and Weaver 2010). And finally, interviewees associated prison itself with both life changing and life stalling effects that complicated the 
presumption that short sentences were always and unconditionally useless, and that prison in longer doses might be helpful. Ironically, then, the premier knowledge product of independent academic research - the peer-reviewed journal article - supported the naturalisation of a statistical population into a real population. Meanwhile, the research report, the low status knowledge product of administrative criminology, carried a message much more subversive and resistant to policy constructions.

The research on 'user views' received a great deal of attention and involved presentations to the Scottish Government and other organisations. In this way, Mark and Katrina came to have further presence, giving all but their real names to a policy process. Their stories told through our research could be bolted onto the technical policy instruments of legislation and subsequent policy programmes, in order to create an almost affective connection between policymakers and the troubled prisoner they sought to help. Here, Mark and Katrina are (re)produced in policy not only through the agency of statistical representation, but also through the humanistic representation of qualitative research as well as wider, longstanding debates about short sentences. At the same time, Mark and Katrina have also shaped policy, becoming, in a way, policy makers; their presence through research has reverberated back through other parts of the policy scene to influence subsequent waves of reform (Scottish Government 2015). Indeed, this assembled set of technicalities, stories and historical context creates a unified narrative establishing the need for policy and reform. Together, they overcome inconsistencies in any single part of the scene; for example, while one statistic became an important impetus for reform, others tended to diminish the relevance of short sentences as a driver of growth (these sentences actually account for a very small proportion of the prison population, meaning that reduction in this group would not significantly affect the overall imprisonment rate). Nor did the well-known but contrary experiences of admired comparators find its way into documentation: Norway's prison system overwhelmingly is used to confine people who are serving sentences of three months or less, challenging the entrenched logic that prison only 'works' when it has a minimum of a year to engage or punish a prisoner.

Approaching this reform as a policy scene has allowed us to show how a particular prison sentence entered into a process, achieved reality and materiality through its transformation into a population, and flowed through and around a site of elites and a site of policy targets, with both settings having transformative effects on understanding and acting on a particular issue. 


\section{Conclusion}

Prisoner presence within policy is only one among an almost countless number of ethnographic opportunities to explore policy as a scene in which meanings (about crime, prison and punishment), desires (of prisoners and policymakers), and paths of action emerge and evolve. Its value here is to provide a discrete example of how one might adopt an ethnographic and scenethinking approach, particularly in sites which are marked by technical language, expert actors, and heterogeneous spaces like conference rooms, prison cells and email. This in turn might help us better understand, explain and avoid situations where policy too often produces the opposite effect to what is desired. Indeed, this was the fate of the Scottish Prisons Commission: although it sought to reduce the prison population, its statistical construction of the 'prison problem,' in terms of the needs of particular prisoners, was accompanied by a response that created new paths of state involvement in these prisoners' lives. Through creation of an expansive community sentence called Community Payback Orders, Scotland has witnessed the expansion of both the prison and community-sentenced population in the years following reform.

However, we resist aggregating this case as just another example of a failed reform, or widened nets of social control, or proof of Foucault's (1977) claim that all attempts to reform the prison have the effect of expanding and legitimizing it. To do so would be to practise one of the ways which criminology typically engages policy and which we criticize here - namely, the reflex to treat what has taken place as inevitable. These are the unexamined and asymmetric assumptions that an ethnographic investigation into policy scenes allows us to unpack.

\section{Notes}

${ }^{i}$ Mark and Katrina are pseudonyms of participants in a research project on 'users' views of punishment (see Armstrong and Weaver 2010, 2013).

${ }^{2}$ http://www.sccjr.ac.uk/projects/user-views-of-punishment/

${ }^{3}$ Scotland has a separate criminal legal and justice system, including a separate prisons service and structure.

${ }^{4}$ http://www.gov.scot/About/Review/spc/About [accessed 16 December 2015]

${ }^{5}$ This latter assumption was often stated and referred to unproblematically in various policy reform conversations throughout the period of the penal policy ethnography, as noted down several times in field notes.

\section{References}


Armstrong, S and Weaver, B. (2013) 'Persistent Punishment: User Views of Short Prison Sentences', The Howard Journal 52(3): 285-305.

Armstrong, S. and Weaver, B. (2010) User Views of Punishment: The Comparative Experience of Short Prison Sentences and Community-based Punishments (Research Report No. 04/2010), Glasgow: Scottish Centre for Crime and Justice Research.

Bennett, A. and Peterson, R.A. (eds.) (2004) Music Scenes: Local, Translocal, and Virtual, Nashville: Vanderbilt University.

Bennett, A. (1999) 'Subcultures or Neo-Tribes? Rethinking the Relationship Between Youth, Style and Musical Taste', Sociology 33(3): 599-617.

Bennett, A. (2004) 'Consolidating the Music Scenes Perspective', Poetics 32(3-4): 223-234.

Blaustein, J. (2015) Speaking Truths to Power: Policy Ethnography and Police Reform in Bosnia and Herzegovina, Oxford: Oxford University Press.

Bosworth, M. and Hoyle, C. (2011) What Is Criminology? Oxford: Oxford University Press.

Bourdieu, P. (2004) Science of Science and Reflexivity, Chicago: University of Chicago Press.

Boutros, A. and Straw, W. (eds.) (2010) Circulation and the City: Essays on Urban Culture, Kingston: McGill-Queen’s University Press.

Carlen, P. (2011) 'Against Evangelism in Academic Criminology: For Criminology as Scientific Art'. In M. Bosworth and C. Hoyle (eds.) What is Criminology? Oxford: Oxford University Press: 96-108.

Clarke, R.V. and Felson, M. (2011) 'The Origins of the Routine Activity Approach and Situational Crime Prevention'. In F.T. Cullen, C.L. Johnson, A.J. Myer and F. Adler (eds.) The Origins of American Criminology: Advances in Criminological Theory (volume 16), New Brunswick, NJ: Transaction. 
Clarke, J., Bainton, D., Lendvai, N., Stubbs, P. (2015) Making Policy Move: Towards a Politics of Translation and Assemblage, Bristol: Policy Press.

Cullen, F.T. (2011) 'Beyond Adolescence-Limited Criminology: Choosing our Future - The American Society of Criminology 2010 Sutherland Address', Criminology 49(2): 387-330.

Davis, K., Fisher, A., Kingsbury, B. and Engle Merry, S. (eds.) (2012) Governance by Indicators: Global Power through Quantification and Rankings, New York: Oxford University Press.

Engle Merry, S., Davis, K. and Kingsbury, B. (eds.) (2015) The Quiet Power of Indicators, Cambridge: Cambridge University Press.

Ericson, R.V. and Carriere, K. (1994) 'The Fragmentation of Criminology'. In D. Nelken (ed.) The Futures of Criminology, London: Sage: 89-109.

Faraldo Cabana, E. (2015) 'A Certain Sense of Fairness? Why Fines Were Made Affordable', European Journal of Criminology 12(5): 616-631

Foucault, M. (1977) Discipline and Punish, NY: Random House.

Garland, D. (2002) ‘Of Crimes and Criminals: The Development of Criminology in Britain'. In M. Maguire, R. Morgan and R. Reiner (eds.) The Oxford Handbook of Criminology, 2nd edn, Oxford: Oxford University Press.

Gieryn, T.F. (1983) 'Boundary-Work and the Demarcation of Science From Non-Science: Strains and Interests in Professional Interests of Scientists', American Sociological Review 48(6): 781795.

Glass, P.G. (2012) 'Doing Scene: Identity, Space, and the Interactional Accomplishment of Youth Culture', Journal of Contemporary Ethnography 41(6): 695-716.

Minogue, M. (1977) 'Theory and Practice in Public Policy Administration', Policy and Politics 11(1): 63-85. 
Haggerty, K.D. and Ericson, R.V. (2000) 'The Surveillant Assemblage', British Journal of Sociology 51(4): 605-622.

Hope, T. and Walters, R. (2008) Critical Thinking about the Uses of Research, King's College London: Centre for Crime and Justice Studies.

Hough, M. (2014) 'Confessions of a Recovering “Administrative Criminologist”: Jock Young, Quantitative Research and Policy Research', Crime Media Culture 10(3): 215-226.

Irwin, J. (1977) Scenes, Beverly Hills, CA: Sage.

Latour, B. and Woolgar, S. (1986) Laboratory Life: The Construction of Scientific Facts, Princeton, NJ: Princeton University Press.

Latour, B. (1987) Science in Action: How to Follow Scientists and Engineers Through Society, Cambridge, MA: Harvard University Press.

Latour, B. (2005) Reassembling the Social, Oxford: Oxford University Press.

Law, J. and Singleton, V. (2005) ‘Object Lessons’, Organization 12(3): 331-355.

Loader, I. and Sparks, R. (2011) Public Criminology? London: Routledge.

MacAskill, K. (2007) Debate on Penal Policy, Speech, http://www.gov.scot/About/Review/spc/About/Review/penalpolicy [accessed 22 December2015]

Mulholland, H. (2007) 'Scottish Executive Scraps Private Prison Plan', The Guardian (23 August); http://www.theguardian.com/politics/2007/aug/23/scotland.devolution [accessed 22 December 2015]

Newburn, T. (2003) Crime and Criminal Justice Policy, Harlow: Pearson Longman. 
O’Malley, P. (1996) 'Post-Social Criminologies: Some Implications of Current Political Trends for Criminological Theory and Practice', Current Issues in Criminal Justice 8(1): 26-38.

Pavlich, G. (2000) Critique and Radical Discourses on Crime. London: Ashgate.

Riles, A. (2005) 'A New Agenda for the Cultural Study of Law: Taking on the Technicalities', Buffalo Law Review, 53: 973-1033.

Scottish Parliament (2009) Criminal Justice and Licensing (Scotland) Bill - POLICY

MEMORANDUM, Stage 3 (5 March 2009).

http://www.scottish.parliament.uk/S3 Bills/Criminal $\% 20$ Justice $\% 20$ and $\% 20$ Licensing $\% 20 \% 28$

$\underline{\text { Scotland } \% 29 \% 20 B i l l / b 24 s 3-i n t r o d-p m . p d f}$ [accessed 22 December 2015]

Riles, A. (ed.) (2006) Documents: Artifacts of Modern Knowledge, Ann Arbor, MI: University of Michigan Press.

Rock, P. (1994) History of Criminology, Aldershot: Dartmouth.

Scottish Government (2015) Consultation on Proposals to Strengthen the Presumption against Short Periods of Imprisonment, http://www.gov.scot/Publications/2015/09/8223

Scottish Government (2012) Prison Statistics Scotland 2011/12, Statistical Bulletin CrJ/2007/7, Edinburgh: Scottish Government.

Scottish Prisons Commission (SPC) (2008) Scotland's Choice: Report of the Scottish Prisons Commission, Edinburgh: Scottish Government.

Shank, B. (1994) Dissonant Identities: The Rock 'n Roll Scene in Austin, Texas, Hanover: Wesleyan University Press.

Shore, C. and Wright, S. (eds.) (1997) Anthropology of Policy: Critical Perspectives on Governance and Power, London: Routledge. 
Shore, C., Wright, S. and Però, D. (eds.) (2011) Policy Worlds: Anthropology and Analysis of Contemporary Power, New York: Bergahn Books.

Star, S.L. (1999) 'The Ethnography of Infrastructure', American Behavioral Scientist 43(3): 377-391.

Strathern, M. (2000) Audit Cultures, London: Routledge.

Straw, W. (2001) 'Scenes and Sensibilities', Public 22/23: 245-257.

Straw, W. (2015) 'Some Things a Scene Might Be’, Cultural Studies 29(3): 476-485.

Weaver, B. and Armstrong, S. (2011) The Dynamics of Community-based Punishment: Insider Views from the Outside (Research Report No. 03/2011), Glasgow: Scottish Centre for Crime and Justice Research.

Woo, B., Rennie, J. and Poyntz, S.R. (2015) 'Scene Thinking', Cultural Studies 29(3): 285-297.

Wright, S. and Reinhold, S. (2011) "Studying Through": a Strategy for Studying Political Transformation'. In C. Shore, S. Wright and D. Pero (eds.) Policy Worlds: Anthropology and Analysis of Contemporary Power, New York: Bergahn Books: 86-104.

Young, J. (1986) 'The Failure of Criminology: The Need for a Radical Realism. In R. Matthews and J. Young (eds.) Confronting Crime, London: SAGE Publications. 